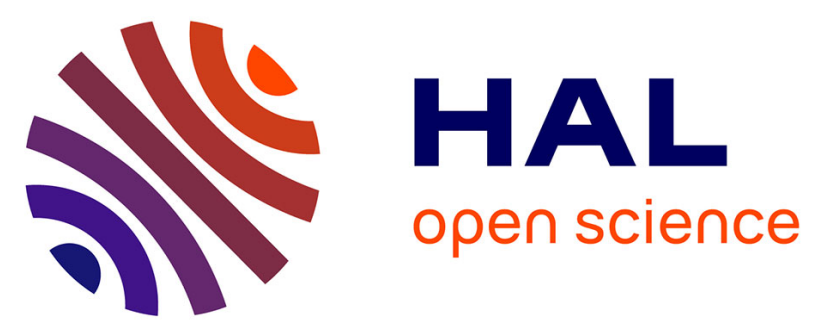

\title{
Alternative control of littleseed canary grass using eucalypt oil
}

Daizy Rani Batish, Harminder Pal Singh, Nidhi Setia, Ravinder Kumar Kohli, Shalinder Kaur, Surender Singh Yadav

\section{> To cite this version:}

Daizy Rani Batish, Harminder Pal Singh, Nidhi Setia, Ravinder Kumar Kohli, Shalinder Kaur, et al.. Alternative control of littleseed canary grass using eucalypt oil. Agronomy for Sustainable Development, 2007, 27 (3), pp.171-177. hal-00886343

\section{HAL Id: hal-00886343 \\ https://hal.science/hal-00886343}

Submitted on 1 Jan 2007

HAL is a multi-disciplinary open access archive for the deposit and dissemination of scientific research documents, whether they are published or not. The documents may come from teaching and research institutions in France or abroad, or from public or private research centers.
L'archive ouverte pluridisciplinaire HAL, est destinée au dépôt et à la diffusion de documents scientifiques de niveau recherche, publiés ou non, émanant des établissements d'enseignement et de recherche français ou étrangers, des laboratoires publics ou privés. 


\title{
Alternative control of littleseed canary grass using eucalypt oil
}

\author{
Daizy Rani BATISH ${ }^{\mathrm{a} *}$, Harminder Pal SINGH ${ }^{\mathrm{b}}$, Nidhi SETIA ${ }^{\mathrm{a}}$, Ravinder Kumar KOHLI ${ }^{\mathrm{ab}}$, Shalinder KAUR ${ }^{\mathrm{a}}$, \\ Surender Singh YADAV ${ }^{\mathrm{a}}$ \\ ${ }^{a}$ Department of Botany, Panjab University, Chandigarh 160014, India \\ ${ }^{\mathrm{b}}$ Centre for Environment and Vocational Studies, Panjab University, Chandigarh 160014, India
}

(Accepted 12 February 2007)

\begin{abstract}
Globally, huge amounts of synthetic herbicides are used to manage weeds in arable lands. However, their widespread use has resulted in various toxicological effects on the environment and human health, besides resulting in the emergence of herbicide-resistant weed biotypes. To overcome these problems, there is an urgent need to search for novel compounds, particularly natural plant products, with potential herbicidal activity. In this area, we studied the phytotoxic effect of volatile oil from lemon-scented eucalypt on littleseed canary grass, a noxious weed of wheat fields. Our findings show that under laboratory conditions the emergence and earlier growth of the weed decreased and completely ceased using a very low concentration of eucalypt oil $(0.0714 \%, \mathrm{v} / \mathrm{v})$. Treatment with eucalypt oil of the 4-week-old pot-raised weeds caused visible damage such as chlorosis and necrosis, wilting and even plant death. The effect was concentration-dependent. At low concentrations, 2.5 and $5 \%, \mathrm{v} / \mathrm{v}$ of eucalypt oil, plants were damaged but recovered later, whereas at concentrations higher than 5\%,v/v, of eucalypt oil plants showed severe injury with little or no sign of recovery, and death. There was a severe effect on the photosynthetic and respiratory ability of treated plants 7 and 21 days after treatment. Eucalypt oil treatment caused a rapid electrolyte leakage in the $P$. minor leaf tissues, indicating a loss of membrane integrity. The study concludes that lemon-scented eucalypt oil offers a good option for control of littleseed canary grass and could be included as a viable component of integrated weed management under sustainable agricultural practices.
\end{abstract}

dose-response / growth reduction / solute leakage / visible injury / chlorophyll content / respiratory activity / bioherbicide

\section{INTRODUCTION}

Phalaris minor Retz., family Poaceae, commonly known as small-seeded or littleseed canary grass, is a troublesome weed of wheat fields in India (Singh S. et al., 1999). Its interference with wheat crops reduces both the quality and quantity of produce. The management of this weed is a big challenge owing to its mimicry of wheat crops and evolution of herbicidal resistance towards herbicide isoproturon. In India, since the first report of its herbicidal resistance towards isoproturon, the weed has spread to most fertile farming land and has even threatened the viability of wheat in wheat-rice cropping systems (Singh S. et al., 1999). This has resulted in excessive use of herbicides, which may have long-term effects on environmental sustainability and human health. There is thus a need to search for alternative chemicals for effective and sustainable management of $P$. minor. In this context, efforts are being made towards a search for chemicals that quickly break down in the environment and possess novel target sites. Natural plant products that play a variety of physiological roles possess these two properties and thus can serve as a source of novel herbicides (Duke et al., 2000). Since antiquity, natural volatile essential oils from aromatic plants have been known for their characteristic odour and antifungal and insecticidal properties. These have been ranked as crop protectants because of their low mammalian toxicity and safety to the user and environment (Isman, 2000). Essential oils from a number

*Corresponding author: daizybatish@yahoo.com of aromatic plants are allelopathic and suppress the growth of other plants (Singh H.P. et al., 2003). Recently, studies have explored their utilisation for weed management under organic agricultural practices (Dudai et al., 1999; Tworkoski, 2002; Angelini et al., 2003; Mowe et al., 2004). It is thus worthwhile to explore the utilisation of essential oils for the management of $P$. minor as a component of an Integrated Weed Management (IWM) strategy.

In the search for potential sources of essential oils, Eucalyptus citriodora, commonly known as lemon-scented eucalypt, was selected for the present study. It is a tall, graceful tree with drooping foliage and planted in Indian plains in gardens, parks, roadsides and in farmers' fields under various forestry and agroforestry programmes. The leaves and even buds and stem of the tree yield an essential oil that is commercially important due to a rich content of citronellal. The oil possesses pesticidal (nematicidal and antibacterial as well as antifungal) properties, and is used in perfumery and as a flavouring agent (Isman, 2000; Cimanga et al., 2002; Ramezani et al., 2002). Further, a number of eucalypt species are allelopathic and suppress other plants by releasing volatile oils into the surrounding environment (Alves et al., 1999). Recently, their oil has been found to suppress the germination, growth and chlorophyll content of several plants, including weeds such as Parthenium hysterophorus, Amaranthus viridis, Cassia occidentalis and Echinochloa crus-galli (Batish et al., 2004; Singh H.P. et al., 2005). Further, the oil possesses some species specificity and among tested species, the inhibitory effect was 
more against Amaranthus viridis and less against others such as Raphanus sativus, maize and wheat (Batish et al., 2004). Keeping in mind the phytotoxicity of eucalypt oil, the objective of the present study was to assess the phytotoxic effects of eucalypt oil against Phalaris minor through a series of laboratory and pot experiments with a view to exploring its use as one viable option under Integrated Weed Management.

\section{MATERIALS AND METHODS}

\subsection{Extraction of essential oil}

Mature and healthy leaves of lemon-scented eucalypt (Eucalyptus citriodora Hook.) were collected from the nearly 25-year-old trees growing on the campus of Panjab University, Chandigarh, India. These were fully expanded, mature, and green in colour, and collected at a height of nearly $6 \mathrm{~m}$ from the ground level. The leaves have an average chlorophyll content of $2.81 \pm 0.15 \mu \mathrm{g} / \mathrm{mg}$ dry weight, protein content of $79.4 \pm 1.24 \mathrm{mg} / \mathrm{g}$ dry weight, and $\mathrm{C} / \mathrm{N}$ ratio of 39.73 (Batish et al., 2006). Volatile oil was extracted from freshly collected leaves by steam distillation using Clevenger's apparatus. For this, 250 grams of freshly chopped leaves were mixed with 1 litre of distilled water in a 2-litre round-bottom flask fitted with a condenser. The mixture was boiled for 1 hour and oil collected from the nozzle of the condenser. It was dried using sodium sulphate and stored at $4{ }^{\circ} \mathrm{C}$ until further use. The chemical composition of the eucalypt oil used in the present study has been reported elsewhere (Batish et al., 2006). The oil was a composite mixture of a variety of monoterpenes such as citronellal, citronellol, isopulegol, isoisopulegol, linalool and $\beta$-citronellene, with citronellal being the major one, followed by citronellol and isopulegol isomers (Batish et al., 2006).

\subsection{Dose-response studies under laboratory conditions}

Seeds of littleseed canary grass (Phalaris minor Retz.) were collected locally from the infested wheat fields selected on the outskirts of Chandigarh, India. These were scarified using concentrated sulphuric acid for 2 minutes and washed with distilled water three times. Scarified seeds divided into seven groups of 100 each were soaked in distilled water for $18 \mathrm{~h}$ for imbibition prior to dose-response germination testing. Imbibed seeds were placed equidistantly in 15 -cm-diameter Petri dishes (5 Petri dishes; 20 seeds each) lined with a double layer of Whatman no. 1 filter paper moistened with $7 \mathrm{~mL}$ of distilled water. The filter paper was treated with $1.428 \times 10^{-3}$, $3.57 \times 10^{-3}, 7.14 \times 10^{-3}, 14.28 \times 10^{-3}, 35.7 \times 10^{-3}$ and $71.4 \times 10^{-3} \%(\mathrm{v} / \mathrm{v})$ or 0 (control) of eucalypt oil. The concentrations used in the present study were based on an earlier study (Batish et al., 2004). Immediately after treatment, Petri dishes were sealed with paraffin film. A similar set-up without eucalypt oil treatment served as control. For each treatment, there were five replicates of 100 seeds ( 20 seeds each in 5 Petri dishes) with a total of 25 Petri dishes. All the Petri dishes were placed in a completely randomised manner inside a growth chamber at $20 \pm 2^{\circ} \mathrm{C}$ temperature, $16 / 8 \mathrm{~h} \mathrm{light/dark} \mathrm{photope-}$ riod of approximately $150 \mu \mathrm{mol} / \mathrm{m}^{2} / \mathrm{s}$ photon flux density and a relative humidity of around $70 \%$. After one week, the number of germinated seeds and length (including both root and shoot) and dry weights of emerged seedlings were measured. Besides, the leaves (cotyledonary) were plucked from emerged seedlings and their chlorophyll content and respiratory values determined. The entire experiment was repeated.

\subsection{Determination of total chlorophyll content}

Since visually the seedlings emerged during the laboratory dose-response study had yellow cotyledonary leaves, indicating a sign of chlorosis, we determined chlorophyll content. Moreover, the spray-treated plants were also visibly paler and yellow in colour. Chlorophyll content gives an indirect idea of the effect of oils on the photosynthetic apparatus of the target plants, as any change in its content is likely to affect the photosynthetic ability and thus growth of the plants.

For all plants from all treatments, chlorophyll was extracted from $25 \mathrm{mg}$ of leaves in $4 \mathrm{~mL}$ of dimethyl sulphoxide (DMSO) following the method of Hiscox and Israelstam (1979). Its concentration was determined spectrophotometrically as per the equation of Arnon (1949) and expressed on a dry weight basis as suggested by Rani and Kohli (1991).

\subsection{Estimation of respiratory activity}

Respiratory activity was not measured per se as $\mathrm{CO}_{2}$ exchange, but rather indirectly as a measure of tissue viability using 2,3,5-triphenyl tetrazolium chloride (TTC). TTC captures the electrons from the mitochondrial electron transport chain and forms a red-coloured formazan. It provides an indirect measurement of cellular respiration (Maness et al., 1999). In other words, it provides an idea of the loss of viability/death of the plants, as visually observed, in response to eucalypt oils. Furthermore, the essential oils, being lipophilic, affect the functioning of membranes, so any change is likely to manifest in altered cellular respiration as the chain is attached to the mitochondrial membrane.

Respiratory activity was determined indirectly using 2, 3, 5-triphenyl tetrazolium chloride following the method of Steponkus and Lanphear (1967). In this method, waterinsoluble red formazan so formed was extracted in ethanol, its absorbance read at $530 \mathrm{~nm}$ and the values expressed with respect to the control.

\subsection{Greenhouse study}

Fifteen seeds of $P$. minor were sown in 15 -cm polypropylene pots, each pot filled with $1500 \mathrm{~g}$ of garden soil (soil:sand, $3: 1, w / w)$. A week after emergence, these were thinned to 7 seedlings per pot. The plants were watered daily and grown under experimental dome conditions with a day:night cycle of $14 \mathrm{~h}$ light:10 $\mathrm{h}$ dark; photoperiod of approximately 
$150 \mu \mathrm{mol} / \mathrm{m}^{2} / \mathrm{s}$ photon flux density; day/night temperature of $22 \pm 2{ }^{\circ} \mathrm{C} / 12 \pm 2{ }^{\circ} \mathrm{C}$; and a relative humidity of around $75 \pm 3 \%$. On the 7 th and 21 st days after emergence, pots were flushed with half-strength Hoagland nutrient solution (Hoagland and Arnon, 1950). When the plants were 4 weeks old (at the 3-4 leaf stage), these were spray-treated with 0 (control), $0.5,2.5,5,7.5$ and $10 \%(\mathrm{v} / \mathrm{v})$ of eucalypt oil solution applied (@125 mL.m ${ }^{-2}$ ) with a handheld sprayer. These concentrations were different from those used in the laboratory bioassay and based on an earlier study against Echinochloa crus-galli and Cassia occidentalis (Batish et al., 2004). There were five replicates per treatment, maintained in a completely randomised manner. Seven and 21 days after treatment (DAT), three plants were uprooted from each pot, their dry weight was determined and leaves were subjected to estimation of chlorophyll content and respiratory activity (as detailed above). Dry weight was determined after keeping the plants in an oven at $75^{\circ} \mathrm{C}$ for $72 \mathrm{~h}$.

\subsection{Effect on membrane leakage}

Another experiment was performed to study the impact of lemon-scented eucalypt oil on the membrane integrity by measuring solute (ion) leakage from the $P$. minor tissue upon treatment with eucalypt oil, following the method of Duke and Kenyon (1993). For this, $100 \mathrm{mg}$ fresh leaves were collected from 3-week-old plants of $P$. minor (2-leaf stage) grown in the experimental dome under the same set of conditions as described earlier for the greenhouse studies. These were dipped in $5 \mathrm{~mL}$ of $1 \mathrm{mM}$ buffer (2-[N-morpholino] ethanesulphonic acid sodium salt, $\mathrm{pH} 6.5$ ) containing $2 \%$ sucrose with eucalypt oil (at the concentration $\left.\left(28.56 \times 10^{-3}\right) \%, \mathrm{v} / \mathrm{v}\right)$ dissolved in Tween-80. The concentration used was based on $\mathrm{IC}_{50}$ values (ranging from $\left.\left((14.4-38.0) \times 10^{-3}\right) \%, \mathrm{v} / \mathrm{v}\right)$ obtained in a dose-response experiment under laboratory conditions. A parallel control was maintained containing the same amount of Tween- 80 but without eucalypt oil. The conductivity of the bathing medium containing plant tissue with or without eucalypt oil was determined using a conductivity meter (ECOSCAN CON5, Eutech Instuments Pte. Ltd., Singapore). Measurements were made at regular intervals $(0,1,2$, $4,8,12,16,18$ and $20 \mathrm{~h}$ ) for 20 hours in the dark followed by exposure to light for 10 hours (at 22, 24, 26, 28 and $30 \mathrm{~h}$ ). Maximum electrolyte leakage was determined by measuring the conductivity of samples after boiling for 10 minutes. The whole experiment was repeated with 5 replicates each time.

\subsection{Statistical analysis}

For each experiment, there were five replicates per treatment in a completely randomised block design. All experiments were repeated to ensure the reproducibility of results and the data presented is a mean of two experiments. The data for seed germination, seedling length and weight determined after one week were subjected to dose-response analysis. Dose-response curves were derived by plotting the concentration (on the $\mathrm{x}$-axis, log scale) and percent response (on

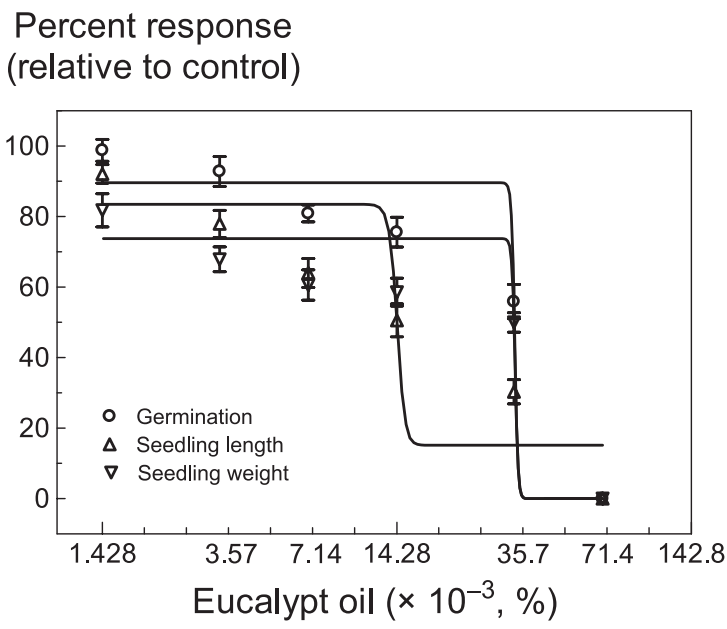

Figure 1. Dose-response curves showing the effect of eucalypt oil on germination and seedling growth, measured after 7 days. Vertical bars along each data point represent the standard error.

the y-axis) using GraphPad Prism version 4 , and $\mathrm{IC}_{50}$ values determined from the response curve. Chlorophyll content and respiratory value, and dry weights determined after foliar treatment of 4-week-old $P$. minor plants under experimental dome conditions are presented as percent reduction relative to control, and analysed by regression models using SPSS/PC software version 10 .

\section{RESULTS AND DISCUSSION}

\subsection{Effect on germination and early growth}

Germination and initial growth of $P$. minor decreased significantly in response to treatment with lemon-scented eucalypt oils (Fig. 1). At $\left(7.14 \times 10^{-3}\right) \%(\mathrm{v} / \mathrm{v})$ eucalypt oil, germination ceased, whereas at lower concentrations it was significantly less compared with control. The magnitude of the inhibitory effect was more on seedling growth than germination (Fig. 1). It was also evident from $\mathrm{IC}_{50}$ values, i.e. those concentrations at which there was a $50 \%$ inhibition. It was $\left(14.31 \times 10^{-3}\right) \%(\mathrm{v} / \mathrm{v})$ for seedling length, $\left(36.02 \times 10^{-3}\right) \%$ $(\mathrm{v} / \mathrm{v})$, for seedling weight and $\left(35.92 \times 10^{-3}\right) \%(\mathrm{v} / \mathrm{v})$ for germination. We have presented the data on seedling length rather than shoot or root length, as there was not much difference in the inhibition levels of roots and shoots when measured separately. These results indicate that lemon-scented eucalypt oil severely affects emergence and early seedling growth of $P$. minor, and its phytotoxicity is worth further exploration.

Though the mechanism of the inhibitory effect of eucalypt oils remains unknown, it might be speculated that eucalypt oil inhibits the mitotic activity of growing cells. It becomes pertinent in view of available reports that volatile terpenes from Salvia spp. (Lorber and Muller, 1976), cineole (Romagni et al., 2000), cineole herbicide - cinmethylin (El-Deek and Hess, 1986), and essential oils from cinnamon (Cinnamomum zeylanicum Blume) and red thyme (Thymus vulgaris L.) (Vaughn, 


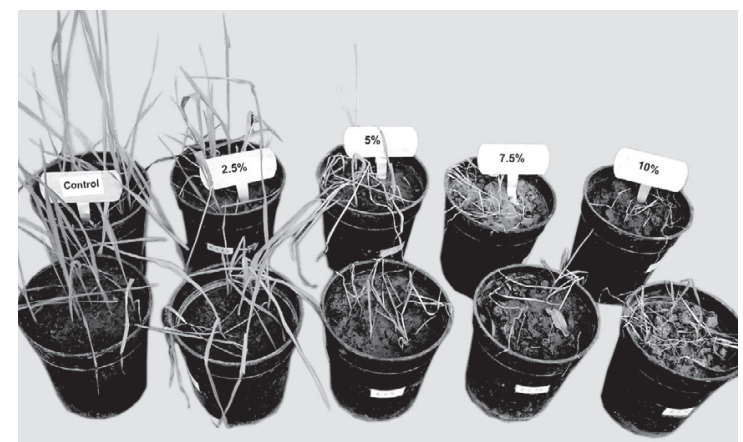

Figure 2. Photograph showing the effect of lemon-scented eucalypt oil at different concentrations on $P$. minor. At a low concentration $(2.5 \%, \mathrm{v} / \mathrm{v})$, there was a reduction in growth and appearance of small brown-coloured necrotic spots. With an increase in concentration, the number and size of necrotic spots increased and plants started wilting. At 5\% spray-treatment concentration, plants were very poor in growth, wilted and almost killed; whereas at still higher concentrations, plants were completely suppressed. It shows that eucalypt oils possess potential for use as a bioherbicide against $P$. minor.

1991) impair the mitotic activity. Treatment of onion cells (data not presented) proved that eucalypt oil is able to disrupt mitosis.

\subsection{Effect of eucalypt oil on $P$. minor under greenhouse conditions}

Application of the lemon-scented eucalypt oils on the potraised 4-week-old $P$. minor plants under greenhouse conditions caused phytotoxic symptoms including wilting, discolouration of plants and formation of necrotic spots (Fig. 2). There was even a gradual loss of weight of $P$. minor plants measured 7 and 21 days after treatment (Fig. 3), thereby indicating less carbon accumulation. The weight loss was more after 21 days. At $2.5 \%$ eucalypt oil treatment, plants were initially wilted, and showed a large reduction in chlorophyll content, but recovered after 21 days. However, plants treated with 5\% concentration showed some signs of recovery after 28 days, but with retarded growth and chlorotic leaves.

\subsection{Effect on chlorophyll content and respiratory activity}

The content of chlorophyll pigment and respiratory activity in the one-week-old plants decreased in response to eucalypt oil (Fig. 4, Panel A). In response to $\left(35.7 \times 10^{-3}\right) \%$ (v/v) eucalypt oil, nearly 74 and $55 \%$ reduction in chlorophyll content and respiratory activity of $P$. minor were observed. The $\mathrm{IC}_{50}$ value for chlorophyll content was measured to be $\left(2.38 \times 10^{-3}\right) \%(\mathrm{v} / \mathrm{v})$, whereas $\mathrm{IC}_{50}$ for respiratory activity was $\left(14.88 \times 10^{-3}\right) \%$. Lower $\mathrm{IC}_{50}$ values for chlorophyll content than for respiratory activity indicate that eucalypt oils affect the chlorophyll content even at low concentrations. Even

\section{Percent Reduction}

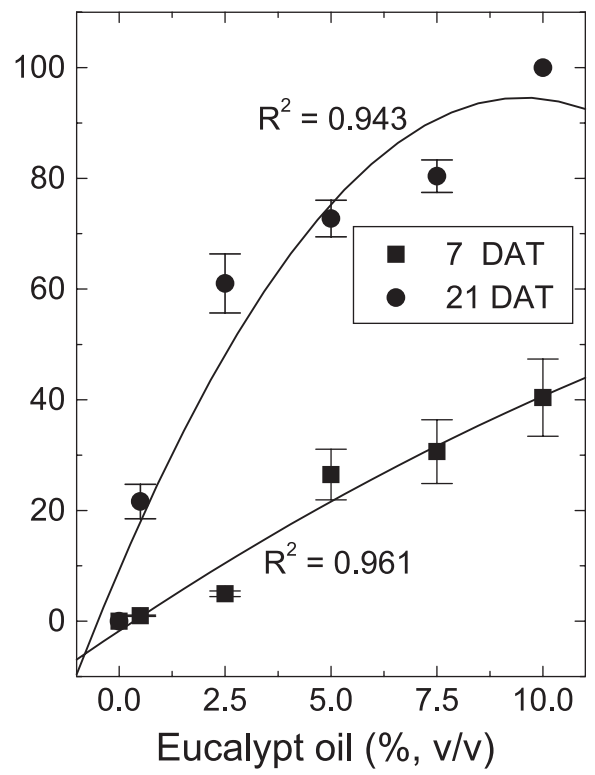

Figure 3. Variation in dry weight in $P$. minor plants measured 7 and 21 days after treatment (DAT) with eucalypt oils under greenhouse conditions. Data presented as percent reduction relative to control and analysed by linear regression. Vertical bars along each data point represent the standard error. $\mathrm{R}^{2}$ represents the correlation coefficient. Dry weight in untreated control plants, 7 DAT $=2.95 \pm 0.24 \mathrm{~g} / \mathrm{plant} ; 21$ DAT $=3.84 \pm 0.31 \mathrm{~g} /$ plant. Regression equation, 7 DAT: $\mathrm{y}=-1.76+$ $5.11 \mathrm{x}-0.09 \mathrm{x}^{2}$ and 21 DAT: $\mathrm{y}=9.24+17.92 \mathrm{x}-0.94 \mathrm{x}^{2}$.

upon spray treatment of $P$. minor plants with eucalypt oil under greenhouse conditions, there was a significant decrease in chlorophyll content and respiratory activity of 4-week-old P. minor plants when measured 7 or 21 days after treatment (Fig. 4, Panel B). The inhibitory effect was concentrationdependent and at lower concentrations $(0.5$ and $2.5 \%)$ the effect was less. In contrast, at higher concentrations $(5 \%$ or more), there was a severe reduction in chlorophyll content as well as respiratory activity. In response to $7.5 \%$ eucalypt oil, chlorophyll content and respiratory activity decreased by nearly 80 and $76 \%$, respectively, after 21 days. Although at lower concentrations $(2.5 \%)$ there was less effect, the plants were visibly weak, and thus competitively poor and caused less interference with the wheat crop.

The negative effect of eucalypt oils on the chlorophyll content and the respiratory activity of $P$. minor under both laboratory assay and spray-treatment studies indicates that oil affects the photosynthetic and respiratory apparatus of $P$. minor plants. Although the exact mechanism of chlorophyll loss due to eucalypt oil treatment is unknown, it could be due to either inhibition of chlorophyll synthesis or enhanced chlorophyll degradation or both; or interference with leaf air diffusibility and related parameters (Polova and Vicherkova, 1986). However, the constituent monoterpenes of eucalypt oil (cineole, citronellal, citronellol and limonene) reduce chlorophyll content, and thus eucalypt oils indirectly interfere with 


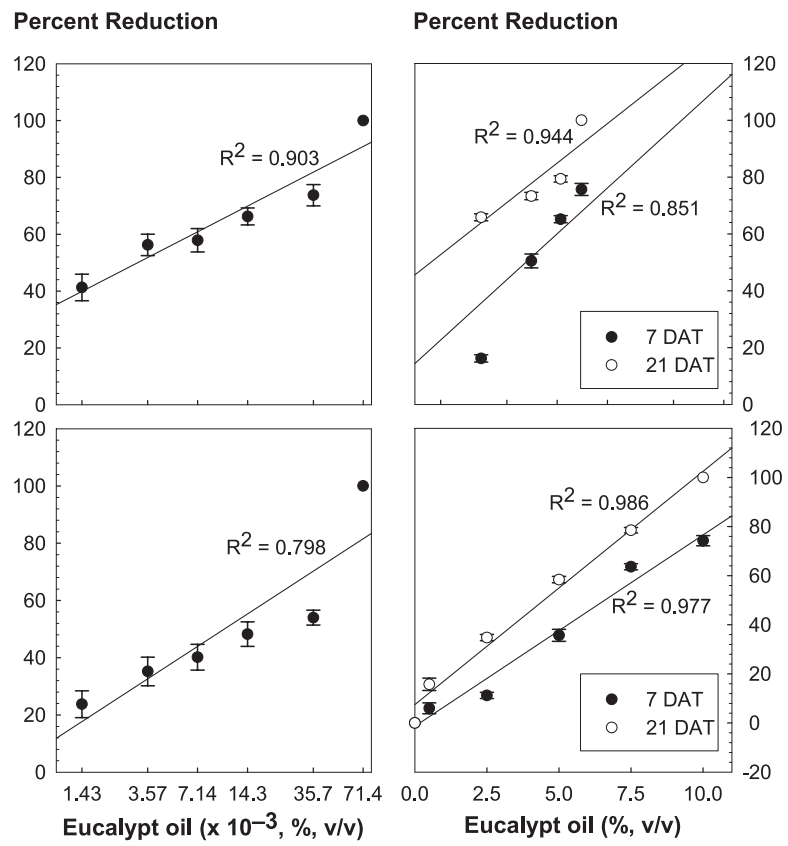

Figure 4. Changes in chlorophyll content (first row) and cellular respiration (second row) in $P$. minor plants in response to eucalypt oil treatment. Data presented as percent reduction relative to control and analysed by linear regression. Left panel depicts 7-day-old plants under laboratory conditions, whereas right panel depicts values determined 7 and 21 days after treatment (DAT) under greenhouse conditions. Vertical bars along each data point represent the standard error. $\mathrm{R}^{2}$ represents the correlation coefficient. Under laboratory conditions, in control seedlings, chlorophyll content $=8.00 \pm 1.40 \mu \mathrm{g} / \mathrm{mg}$, respiratory activity $=1.636 \pm$ 0.267 (mean extinction value at $530 \mathrm{~nm}$ ); under greenhouse conditions, in untreated control, 7 DAT: chlorophyll content $=14.34 \pm$ $0.18 \mu \mathrm{g} / \mathrm{mg}$, respiratory activity $=1.709 \pm 0.218$; in untreated control 21 DAT, chlorophyll content $=14.59 \pm 0.15 \mu \mathrm{g} / \mathrm{mg}$ and respiratory activity $=1.673 \pm 0.048$. Regression equations: under laboratory conditions, chlorophyll content $=35.26+30.03 x$; respiration $=11.88+37.56 \mathrm{x}$; under greenhouse conditions, for chlorophyll content, $7 \mathrm{DAT}=14.37+53.49 \mathrm{x} ; 21 \mathrm{DAT}=45.6+46.1 \mathrm{x}$; for respiration, 7 DAT $=-1.31+7.79 x ; 21$ DAT $=7.53+9.50 x$.

the photosynthetic process (Romagni et al., 2000; Singh H.P. et al., 2002a, b). Recently, essential oils from Dhatelo (Prinsepia utilis Royle) affected the stomatal functioning of faba bean (Vicia faba $\mathrm{L}$.) by inhibiting $\mathrm{K}^{+}$flux in the guard cells (Rai et al., 2003).

A decreased level of chlorophyll directly results in less productivity and thus weaker seedlings, as observed. Further, such weaker seedlings will possibly be under more biotic stress to compete with the crop plants, as also indicated by the effect on respiratory activity. The $\mathrm{IC}_{50}$ value for respiratory activity is greater because during initial stress (induced by low concentration of eucalypt oils) plants could cope by increasing the metabolic rate, whereas at higher concentrations there is probably a severe metabolic dysfunction resulting in decreased respiration rates. The loss of respiratory activity may affect the energy metabolism of the plants, which may in turn

\section{Conductivity $(\mu \mathrm{S})$}

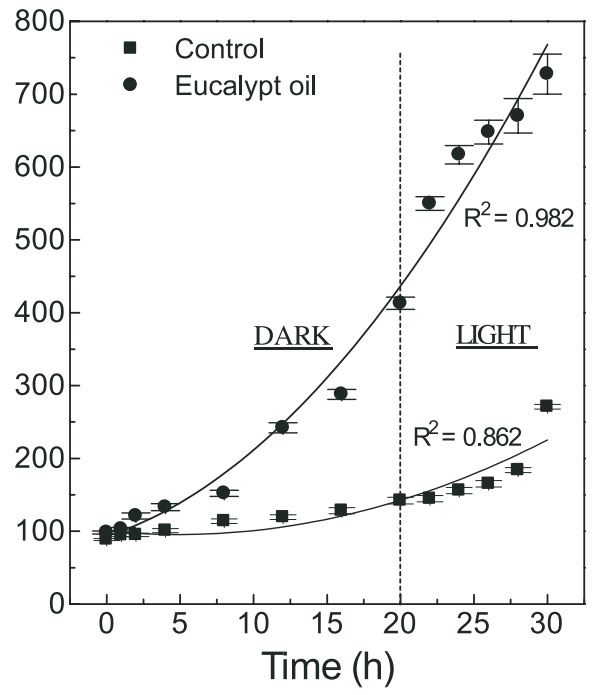

Figure 5. Effect of eucalypt oil on the electrolyte leakage from the $P$. minor leaves. Data analysed by linear regression models and $\mathrm{R}^{2}$ represents the correlation coefficient. Each data point is an average of ten observations and vertical bars along each data point represent the standard error. Dotted vertical line separates $20 \mathrm{~h}$ of dark treatment from $8 \mathrm{~h}$ of light treatment. Maximum ion leakage in control (untreated) leaves upon boiling was $779.2 \pm 11.86 \mu \mathrm{S}$. Regression equation, in control: $\mathrm{y}=100.4-2.0 \mathrm{x}+0.21 \mathrm{x}^{2}$ and in eucalypt oil treatment: $y=93.2+6.5 x+0.53 x^{2}$.

affect the synthesis of macromolecules and subsequent plant growth (Peñuelas et al., 1996). Monoterpenes, the constituent of eucalypt oils, act as uncouplers of oxidative phosphorylation (Abrahim et al., 2000).

\subsection{Effect of eucalypt oil on membrane leakage}

Eucalypt oil caused excessive ion leakage from $P$. minor tissue that resulted in a significant increase in the conductivity of the bathing medium containing eucalypt oil $\left(\mathrm{R}^{2}=0.98\right)$ compared with the control (Fig. 5). The conductivity of the bathing medium increased rapidly with time, becoming prominent after $8 \mathrm{~h}$ and continuing until $30 \mathrm{~h}$, irrespective of the light or dark period. After $8 \mathrm{~h}$, conductivity of eucalypt oiltreated samples was over 2.24 times more than untreated control (Fig. 5) and increased further to nearly 4 times that of control after $24 \mathrm{~h}$. At $30 \mathrm{~h}$, the electrolyte leakage was nearly 93\% of the maximum leakage observed in the boiled tissue. This experiment indicates the possible primary effect of lemonscented eucalypt oils on membrane permeability, which in turn is indicative of oxidative stress. Such an impact of volatile oils on membrane integrity is not new. Earlier, Lorber and Muller (1976) reported that volatile terpenes from Salvia leucophylla damage cell organelle membranes, particularly mitochondrial, resulting in structural breakdown at a cellular level. The disintegration of the mitochondrial membrane in turn severely 
affects the electron transport during the respiratory mechanism. Likewise, Sikkema et al. (1995) and Tworkoski (2002) reported that essential oils and their monoterpenes damage the membrane by causing excessive ion leakage. In the present study, no attempt was made to assess the effect of eucalypt oil on the mitochondrial membrane; however, based upon the available literature, it could be possible that the inhibition of respiration observed at the electron transport level in this study may be due to mitochondrial membrane damage. However, the observed changes in respiratory activity (linked to the chain) and chlorophyll content seem to be the secondary manifestations of eucalypt oil triggered by changes in membrane integrity that could be the primary effect of eucalypt oils.

Though lemon-scented eucalypt oil exerts phytotoxicity against $P$. minor worth exploitation as a bioherbicide, it is difficult to comment upon its use as a pre- or post-emergent as the present study was conducted only under laboratory and experimental domes in simulated conditions, and field studies are lacking. However, based on the available literature (Batish et al., 2004; Singh H.P. et al., 2005), and the results obtained in the present study, it might better be used at post- than preemergent levels. It is easy to extract eucalypt oils from the foliage by hydrodistillation and yield is higher in E. citriodora (1.6-1.7\%; v/w, on a fresh weight basis) compared with E. tereticornis and E. globulus - the other commonly grown species from which oil is extracted in India. Rather, the utilisation of natural plant products (either in pure form or as crude extracts or essential oil) now offers one of the viable options for sustainable weed management (Singh H.P. et al., 2003; Ferron and Deguine, 2005; Xuan et al., 2006). Even some of these, such as parthenin (a sesquiterpene lactone from Parthenium hysterophorus), have shown remarkable activity against billy goat weed (Ageratum conyzoides L.) without any effect on wheat (Batish et al., 1997). As regards the species selectivity of eucalypt oils, earlier studies have established that eucalypt oils exhibit differential activity against different plant species (Batish et al., 2004). These authors observed that eucalypt oils severely impair germination and early growth of Amaranthus viridis (a weed of winter wheat in India) and there was less effect on maize and Raphanus sativus. However, further studies regarding species selectivity against weeds in wheat crops are required to evaluate its utilisation for weed management in wheat fields. The eucalypt oils, being lipophilic, do not dissolve well in water. However, their solubility is not a problem, since constituent monoterpenes are partially soluble and phytotoxic even at lower solubility rates (Weidenhamer et al., 1993). Further, these can be brought into a solution form with some surfactants. Additionally, the use of ionic as well as non-ionic surfactants can reduce the effective concentration of eucalypt oils; although no such report is available concerning eucalypt oils.

\section{CONCLUSION}

The present study concludes that lemon-scented eucalypt oils affect the emergence, growth and physiology of $P$. minor and thus could serve as a possible bioherbicide. Eucalypt oil could also be included as one viable option in place of synthetic herbicides under sustainable agricultural practices involving Integrated Weed Management strategies. These could thus help in maintaining and preserving the sustainability of agricultural land that is fast deteriorating due to residual and toxicological effects of synthetic herbicides.

Acknowledgements: Daizy R. Batish is thankful to the University Grants Commission, India, for providing financial support in the form of a research award to undertake this work. Nidhi Setia and Shalinder Kaur are thankful to the Council of Scientific and Industrial Research, India, for Senior Research Fellowship grants.

\section{REFERENCES}

Abrahim D., Braguini W.L., Kelmer-Bracht A.M., Ishi-Iwamoto E.L. (2000) Effects of four monoterpenes on germination, primary root growth and mitochondrial respiration of maize, J. Chem. Ecol. 26, 611-623.

Alves P.L.C.A., Toledo R.E.B., Gusman A.B. (1999) Allelopathic potential of Eucalyptus spp., in: Narwal S.S. (Ed.), Allelopathy Update, Vol. 2, Basic and Applied Aspects, Science Publishers, Enfield, pp. 131-148.

Angelini L.G., Carpanese G., Cioni P.L., Morelli I., Macchia M., Flamni G. (2003) Essential oils from Mediterranean Lamiaceae as weed germination inhibitors, J. Agr. Food Chem. 51, 6158-6164.

Arnon D.I. (1949) Copper enzymes in isolated chloroplasts: Polyphenylperoxidase in Beta vulgaris, Plant Physiol. 24, $1-15$.

Batish D.R., Kohli R.K., Singh H.P., Saxena D.B. (1997) Studies on herbicidal activity of parthenin, a constituent of Parthenium hysterophorus towards billgoat weed (Ageratum conyzoides), Curr. Sci. 73, 369-371.

Batish D.R., Setia N., Singh H.P., Kohli R.K. (2004) Phytotoxicity of lemon-scented eucalypt oil and its potential use as a bioherbicide, Crop Prot. 23, 1209-1214.

Batish D.R., Singh H.P., Setia N., Kaur S., Kohli R.K. (2006) Chemical composition and phytotoxicity of volatile essential oils from intact and fallen leaves of Eucalyptus citriodora, Z. Naturforsch. c 61, $465-471$.

Cimanga K., Kambu K., Cimanga K., Tona L., Apers S., De Bruyne T., Hermans N., Totte J., Pieters L., Vlietinck A.J. (2002) Correlation between chemical composition and antibacterial activity of essential oils of some aromatic medicinal plants growing in the Democratic Republic of Congo, J. Ethnopharm. 79, 213-220.

Dudai N., Mayer A.M., Putievsky E., Lerner H.R. (1999) Essential oil as allelochemicals and their potential use as bioherbicides, J. Chem. Ecol. 25, 1079-1089.

Duke S.O., Kenyon W.H. (1993) Peroxidizing activity determined by cellular leakage, in: Böger P., Sandmann G. (Eds.), Target Assays for Modern Herbicides and Related Phytotoxic Compounds, CRC Press, Boca Raton, FL, pp. 61-66.

Duke S.O., Dayan F.E., Rimando A.M., Schrader K.K., Aliotta G., Oliva A., Romagni J.G. (2000) Chemicals from nature for weed management, Weed Sci. 50, 138-151.

El Deek M.H., Hess F.D. (1986) Inhibited mitotic entry is the cause of growth inhibition by cinmethylin, Weed Sci. 34, 684-688.

Ferron P., Deguine J.-P. (2005) Crop protection, biological control, habitat management and integrated farming. A review, Agron. Sustain. Dev. 25, 17-24.

Hoagland D.R., Arnon D.I. (1950) The water-culture method for growing plants without soil, University of California Agricultural 
Experiment Station Circular No. 347, The College of Agriculture, University of California, Berkeley.

Hiscox J.D., Israelstam G.F. (1979) A method for extraction of chlorophyll from leaf tissue without maceration, Can. J. Bot. 57, 1332 1334.

Isman M.B. (2000) Plant essential oils for pest and disease management, Crop Prot. 19, 603-608.

Lorber P., Muller W.H. (1976) Volatile growth inhibitors produced by Salvia leucophylla: effects on seedling root tip ultrastructure, Am. J. Bot. 63, 196-200.

Maness P.-C., Smolinski S., Blake D.M., Huang Z., Wolfrum E.J., Jacoby W.A. (1999) Bactericidal activity of photocatalytic $\mathrm{TiO}_{2}$ reaction: toward an understanding of its killing mechanism, Appl. Environ. Microb. 65, 4094-4098.

Mowe L., Henderson G., Laine R.A. (2004) Germination of various weed species in response to vetiver oil and nootkatone, Weed Technol. 18, 263-267.

Peñuelas J., Ribas-Carbo M., Giles L. (1996) Effects of allelochemicals on plant respiration and oxygen isotope fractionation by the alternative oxidase, J. Chem. Ecol. 22, 801-805.

Polova M., Vicherkova M. (1986) Leaf diffusibility changes of bean and sunflower plants treated with essential oil vapours, Scr. Fac. Sci. Nat. Univ. Purkynianae Brunensis (Biol.) 16, 119-128.

Rai V.K., Gupta S.C., Singh B. (2003) Volatile monoterpenes from Prinsepia utilis L. inhibit stomatal opening in Vicia faba L., Biol. Plant. 46, 121-124.

Ramezani H., Singh H.P., Batish D.R., Kohli R.K., Dargan J.S. (2002) Fungicidal effect of volatile oils from Eucalyptus citriodora and its major constituent citronellal, New Zeal. Plant Prot. 55, 327-330.

Rani D., Kohli R.K. (1991) Fresh matter is not an appropriate relation unit for chlorophyll content: experience from experiments on effects of herbicides and allelopathic substances, Photosynthetica 25, 655-657.
Romagni J.G., Allen S.N., Dayan F.E. (2000) Allelopathic effects of volatile cineoles on two weedy plant species, J. Chem. Ecol. 26, 303-313.

Sikkema J., de Bont J.A.M., Poolman B. (1995) Mechanism of membrane toxicity of hydrocarbons, Microbiol. Rev. 59, 201-222.

Singh H.P., Batish D.R., Kohli R.K. (2002a) Allelopathic effects of two volatile monoterpenes against bill goat weed (Ageratum conyzoides L.), Crop Prot. 21, 347-350.

Singh H.P., Batish D.R., Kaur S., Ramezani H., Kohli R.K. (2002b) Comparative phytotoxicity of four monoterpenes against Cassia occidentalis, Ann. Appl. Biol. 141, 111-116.

Singh H.P., Batish D.R., Kohli R.K. (2003) Allelopathic interactions and allelochemicals: new possibilities for sustainable weed management, Crit. Rev. Plant Sci. 22, 239-311.

Singh H.P., Batish D.R., Setia N., Kohli R.K. (2005) Herbicidal activity of volatile oils from Eucalyptus citriodora against Parthenium hysterophorus, Ann. Appl. Biol. 146, 89-94.

Singh S., Kirkwood R.C., Marshal G. (1999) Biology and control of Phalaris minor Retz. (little seed canary grass) in wheat, Crop Prot. $18,1-16$.

Steponkus P.L., Lanphear F.R. (1967) Refinement of triphenyl tetrazolium chloride method of determining cold injury, Plant Physiol. $42,1423-1426$.

Tworkoski T. (2002) Herbicide activity of essential oil, Weed Sci. 50, 425-431.

Vaughn S.F. (1991) Natural compounds from spices could replace potato sprouting inhibitors, Ind. Bioprocess. 13, 5.

Weidenhamer J.D., Macias F.A., Fischer N.H., Williamson G.B. (1993) Just how insoluble are monoterpenes? J. Chem. Ecol. 19, 17991807.

Xuan T.D., Elzaawely A.A., Deba F., Fukuta M., Tawata S. (2006) Mimosine in Leucaena as a potent bio-herbicide, Agron. Sustain. Dev. 26, 89-97. 